\title{
Argentine Geography and the Ancient Pampean Sea
}

\section{Author(s): George Earl Church}

Source: The Geographical Journal, Vol. 12, No. 4 (Oct., 1898), pp. 386-401

Published by: geographicalj

Stable URL: http://www.jstor.org/stable/1774764

Accessed: 27-06-2016 05:01 UTC

\section{Your use of the JSTOR archive indicates your acceptance of the Terms \& Conditions of Use, available at}

http://about.jstor.org/terms

JSTOR is a not-for-profit service that helps scholars, researchers, and students discover, use, and build upon a wide range of content in a trusted digital archive. We use information technology and tools to increase productivity and facilitate new forms of scholarship. For more information about JSTOR, please contact support@jstor.org.

The Royal Geographical Society (with the Institute of British Geographers), Wiley are collaborating with JSTOR to digitize, preserve and extend access to The Geographical Journal 
where landing is possible, and the geology of the island was ascertained. This island is curious indeed, completely covered by an ice-cap (inland ice), which is broken off at the sea-shore, ending in a perpendicular icewall, just as is found on the antarctic continent, although in miniature. Great table-formed icebergs are given off from this ice-sheet. From the White island, which is larger than is indicated on the maps, we made our way through alternating heavy ice and open water to Charles the XII.'s island, whence we went northwards, and reached $81^{\circ} 14^{\prime} \mathrm{N}$. lat. If we had been there a fortnight or so earlier, we should certainly have reached a higher latitude, but northerly winds had prevailed for some time, so the pack had driven south again. We then passed north of the Seven islands, and went to Treuenberg bay, Grey Hook, and Danes island, from which we steered southwards along the western coast of Spitsbergen. When we reached the south end of Prince Charles foreland, the circumnavigation of the whole of Spitsbergen, with the surrounding islands, was completed. I don't know if any vessel has done so before. My intention to go to the Storfjord was made impossible through heavy gales, and having in vain waited almost a week for the weather to improve, I steered southwards, passing Bear island again, and making hydrographical observations.

"The scientific work of the expedition has been most successful; we have large geological, botanical, and zoological collections. The geology, zoology, and botany of King Charles Land is now completely known, and there are important connections between the geology of Spitsbergen and that of Franz Josef Land."

\section{ARGENTINE GEOGRAPHY AND THE ANCIENT PAMPEAN SEA.*}

\section{By Colonel GEORGE EARL CHURCH.}

IXSTEAD of addressing you upon geography as a science, or summarizing the triumphs of explorers during the past year, I shall invite you to accompany me to southern South America-a step towards the antarctic regions-and let me try to add to your knowledge of Argentine geography and the ancient Pampean sea.

The matchless voyage of Magellan gave rise to one, in 1526, for the discovery of "the islands of Tharsis, Ophir, and Eastern Cathay," the command of which was given by Charles V. of Spain to Sebastian Cabot, the son of John. Sebastian, en route, lured by silver-tongued fable, diverted the expedition, sailed for and ascended the Plata estuary and river Paraná, and attempted the conquest of the Plata valley. Disaster attended him; and, with a single ship, he returned to Spain. That valley is now being developed into a prosperous state by the application of $£ 200,000,000$ sterling of European capital-three-fourths of which is British-and is already the home of five millions of thriving, intelligent, and energetic people.

* Presidential Address to the Geographical Section of the British Association, Bristol, September, 1898. Maps and sections, p. 444. 
Sebastian Cabot having been brought up as a boy in this city of Bristol, I have thought it not inappropriate to this occasion to give you some idea of the land which he tried to conquer, and how nature has there marshalled her forces. She has, within easy reach, all the elements she requires for action upon the most imposing scale; and it must be admitted that she has brought them lavishly into play. The present drainage area of the Plata basin is, according to Dr. Bludau, 1,198,000 square miles, being over two and a half times that of the entire Pacific slope of the Andes. The minimum water-discharge into the Plata estuary would, every twenty-four hours, make a lake one mile square and 1650 feet deep. About 74 per cent. of it would represent the flow of the Paraná, and 26 per cent. that of the Uruguay river. In my subject, the latter plays only a secondary part; the majestic Paraná and its branches assume the primary rôle. These interlace with the affluents of the Amazon along a line of 14 degrees of longitude. Even on the ocean, I have been unable to realize vastness, as regards quantity of water, to the extent which I have while standing on the bluff overlooking the Paraná at Rosario, and also on the bank of the Amazon at Obydos. Dark, profound, and mysterious, the rivers ceaselessly roll past, ever in the same direction, never to return; and, awestruck, one reflects that, for æons of ages, they have never halted in their stately march, and asks where and what is the power that gathers and lets loose these mighty floods?

Extent of the Plata Basin in Ancient Times.-I shall try to show that the Plata drainage area was, in a recent geological period, much more extensive than it is to-day; that its most northern limit was in $10^{\circ} 44^{\prime} \mathrm{S}$. lat., and that nearly the entire waters which now unite to form the Madeira river, the main affluent of the Amazon, once flowed southward into a Pampean sea, which penetrated north over the plains of the present Argentine Republic, to about $19^{\circ} \mathrm{S}$. lat.

To elucidate this proposition, I must call attention to the topography of that great Bolivian basin across which the whole northern and eastern slope of the Bolivian Andes and the western slope of Brazilian Matto-grosso send their abundant drainage to the falls of the Madeira. The present elevation of the upper fall has been found, by instrumental survey, to be 547 feet above sea-level. The distinguished engineer, Julio Pinkas, who made the survey, estimated the drainage area of the Bolivian basin at 400,000 square miles. This is somewhat in excess of, but perhaps more accurate than, my own estimate, made when I descended the Mamoré river and the Amazon in 1871. Elsewhere I have shown that the Bolivian rivers lie upon a great plateau, high above the river Purús, as well as above the lower Madeira. The Andes form the south-western and western rim of this plateau; and, between the Mayu-tata and Purús, push low hills north-east towards the falls of the Madeira. On the eastern side are the Matto-grosso highlands, and, south-east, the low Chiquitos sierras of San Juan, the Sunsas, San Lorenzo, Ipias, Chochis, and Santiago, some of them overlooking the Argentine Gran Chaco, and having a southern drainage into the river Paraguay. The grand rim of the Bolivian basin has two breaks; one leads to the Amazon valley, by the falls of the Madeira, and the other, in longitude $62^{\circ}$ west from Greenwich, and latitude $18^{\circ}$ south, opens into what is now known as the Plata basin. Further on, I will attempt to show how a dam was gradually thrown across this southern gap, until its elevation, once much inferior, became superior to that of the ancient lip of the falls over which the Bolivian rivers now plunge.

The mean flow of the Madeira river, at the moment of receiving its united Bolivian tributaries, is, according to Keller, 8654 cubic metres per second, equal to 305,616 cubic feet. Pinkas makes it 6874 cubic metres. These must be rough calculations; for the mean flow of a river of such variable conditions could only 
be accurately measured by a series of observations extending over several years. I believe it is equal to that of the Paraná and Uruguay at their junction.

Outline of the Basin.-The Matto-grosso highlands, overlooking the Bolivian basin, are composed almost wholly of red sandstone, overlying argillaceous schists ; but near the headwaters of the Guapore river, which skirts their western base, are found rose-coloured gneiss, talc schists, and sandstones, on which frequently rest large areas of a recent alluvium, locally called canga.

The Chiquitos sierras rise, on an average, from 1400 to 2000 feet above the sea. (Minchin mentions a peak 3600 feet high.) I agree with Dr. J. W. Evans that, as described by D'Orbigny, they present evidences of belonging to the exrlier Brazilian highlands, rather than the younger elevation of the Andes. The western section is a wall of friable, ferruginous sandstone, sometimes flat-topped, while the extension, towards the Paraguay river, is a compact sandstone overlying talc schist, which, towards the north-east, rests on gneiss in decomposition. The San Juan and Sunsas sierras are the most northern of the Chiquitos group. The former is mostly of gneissic formation, but the latter is of sandstone resting on talc schist.

The Bolivian Andes, which face the Amazon and the Gran Chaco, are almost entirely composed of feldspathic sandstones, micaceous and blue slates, clay and sandy shales, at times showing a thickness of from 10,000 to 15,000 feet. In riding from Cochabamba to Santa Cruz de la Sierra, I have especially noticed them exposed upon a gigantic scale.

The upper fall of the Madeira, called Guajará-mirim, runs over the ferruginous, conglomerate rock called canga. This rests on argillaceous sandstone, which crumbles easily by the action of running water. The canga gradually becomes undermined, and, breaking in pieces, is moved by the currents into deep water: thus the elevation of the fall is gradually lowered. Keller gives a notable example of such erosion, at a point called Matucaré, on the lower Madeira river. All the other barriers which form the falls are varieties of granitic and metamorphic rocks.

About 18 milcs above the mouth of the Beni branch of the Madeira, and below that of the Mayu-tata, is the fall of Esperanza, having a drop of 20 feet in a length of 1000 . According to M. V. Ballivian, the rock is of canga, the same as that of Guajará-mirim.

Pinkas found that, on the right bank of the upper Madeira river, several places are still visible where the erosive action of the waters has stripped the primitive rocks, anciently covered by a bed of ferruginous sandstone. I also saw evidences of the erosive action of the river near the upper falls, and am disposed to believe that, in the lapse of centuries, one or two rapids higher up the river have disappeared; not, however, entirely, for a reef of ferruginous conglomerate still partly crosses the Mamoré river, between the mouth of the Guaporé and the town. of Exaltacion. It is probable that the western Matto-grosso hills once extended westward to the Beni fall of Esperanza, where they met the Andean foothills, and added to the height of the barrier which prevented the river system of Bolivia from breaking through to the north-east. How high that barrier may have been, it is difficult to determine, owing to the country being densely forested; but, in the fork of the Beni and Mamoré, I found hills perhaps 150 feet elevation above the river; and Keller mentions some on the left bank of the Beni near its moutb. The rocks of Matto-grosso are so soft as to offer but slight obstacle to the erosive power of the mighty flood of the Madeira : and, if we admit that the lip of its upper fall, when the river began to flow over it, was only 100 feet higher than now, it will be but a small allowance in comparison to the depths which even unsignificant streams have excavated over the immense area of Matto-grosio. The falls of the: 
Madeira appear to have completely cleared off and exposed the granitic and metamorphic rocks upon which the Matto-grosso shales and sandstones once rested.

Immense quantities of detritus have found their way down the Andes. The volume carried by the little river La Paz, the remotest branch of the Beni, is astounding. I once descended it to ride round the base of Mount Illimani. The river is so hemmed in between the material of the Titicaca basin and that monarch of the Andes, that I had to ford it 108 times in one day. It has cut a profound gorge through the inland range, perhaps 50 feet wide and 600 feet deep. The overhanging precipices looked not over 40 feet wide at the top. Through this dark rent, which I had to penetrate or turn back, the river swept me, horse and all, as if I had been launched from a catapult.

The bed of detritus and alluvium, which the river skirts for about 50 miles, is one of the most remarkable in the world. Forbes gives it a total thickness of 2000 to 2500 feet " of alternating beds of grey, bluish, and fawn-coloured clays, gravel and shingle beds, with boulders of clay slate, greywacké, and granite, frequently of enormous size and well rounded, as if by the action of water." In my ride down the valley, I saw nature at work tearing into this deposit, and sending it on its way to the great basin of the Beni and Mojos. During certain months, generally from November to March, a prolonged and violent local storm may arise in scme lateral valley of the river. The waters then sweep impetuously down, taking with them hundreds of thousands of cubic yards of material which they pile across the La Paz river. The mass of clay and boulders rapidly becomes cemented and compacted, and holds its place until the La Paz in turn, swollen by some storm from Illimani, bursts the huge dam and hurls its contents down the valley. I noticed boulders of many tons weight, at least 300 feet above the bed of the river, sticking, like half-exposed marbles, in the side of the perpendicular wall of detritus which towered even high above them.

Similar denudation is going on along the entire Andean slope. The great Rio Grande carries a prodigious mass of alluvium into the gap which lies between the extreme eastern counterfort of the Andes and the Chiquitos sierras. Even its little branch, the Piray, which I descended, desolates the country far and wide, in periods of flood, with trees, sand, and mud. The Rio Grande and the Parapiti must have transported to the plain, to the east of Santa Cruz de la Sierra, millions on millions of cubic yards of material, and have filled it to a depth of several hundred feet. The examples I have given, from personal observation, can, however, but faintly convey an idea of the grand scale upon which nature is at work tearing down the Atlantic slope of the Bolivian Andes. So far, she has succeeded in only outlining the task she has assumed; for she appears to have finished nothing. The finer touches cannot be put on with such riotous vigour.

Later, I shall show how the closing of the southern gap caused the formation of a lake in the Bolivian Mojos basin, the lacustrine character of which is not yet eliminated; for, during a period of about four months of the year, some 35,000 square miles of its surface are covered with the surplus water which cannot find exit over the falls of the Madeira, they not yet having been worn down enough to give complete drainage to the basin; or else this is not yet sufficiently silted up to keep it out of water. Castlenau says that, "Due to their horizontality, all the plains, from the mouth of the Mamore to the Pilcomayo, are inundated from October to March, and present the aspect of a great ocean dotted with green islands ;" and, speaking of the great southern gap, says, "Across the Monde Grande, a simply overturned tree would change the course of the waters." D'Orbigny is eloquent in his descriptions of the "smooth surface" and " unlimited horizon" of the vast plains of Mojos and the Beni. 
Between Santa Cruz de la Sierra and the northern frontier of the Argentine Republic, the Pilcomayo river gathers its waters amidst masses of red sandstone and argillaceous schists. Further southward, the Andes are broken into a number of secondary ridges of palæozoic composition, among which are the sources of the Bermejo and Salado. In the most southern extension of these ridges, we find limestones and compact sandstones, mica schist, gneiss, and granite. From about lat. $30^{\circ} \mathrm{S}$., the Andes lose their great width, and thence confine themselves to the Pacific coast ridge, as far south as the Straits of Magellan. According to De Moussy, "the lower sierras, which lie to the east, present a great variety of stratified, crystalline rocks, saccharoids, slate schists, bituminous sandstone, basalts, obsidian, trachites, pumice, crystallized and amorphous quartz."

The Sierra de Cordova, extending north and south for nearly 300 miles, and having a summit about 7500 feet above ocean-level, was probably an ancient group of islands in the Pampean sea. It consists of several parallel chains, composed principally of quartz, gneiss, and limestones of various colours. De Moussey found trachitic rocks on their northern extension, and evidences of volcanic action. South-west, and separated from the Sierra de Cordova, is the low San Luis range of gneiss and mica schist, and sometimes crystallized quartz. Vast masses of rounded shingle, covered by a thin cap of argillaceous earth and coarse granitic sand, border the valleys. The Alto Penasco sierra, 40 miles west of the San Luis range, is also composed of crystalline rocks. The Cordon de Paramillos, near Mendoza, is of porphyry, sandstone, schists, and limestone. Here also, "immense quantities of rounded and rolled shingle cover the base of all the chains and interior valleys. The torrents cut the accumulated débris to a profound depth, and expose its enormous thickness. The bottoms of the valleys are entirely composed of it."

Penetrating north of Mendoza, we find white sandstone, and mountains of red sandstone and argillaceous conglomerate in full process of decomposition. These abound, above all, in the provinces of La Rioja and Catamarca.

Southern Extremity of the Basin.-From Cape Corrientes inland, ranges of hills, irregularly massed in line, extend north-west about 150 miles. They are known as the Sierra de Tandil, and are widest at Tandil. Their greatest elevation above the sea is 1476 feet. My old friends, Heusser and Claraz, say the range is "composed of sandstone caps resting on gneissic-granite, showing the Pampean formation in the valleys and on their slopes." Sometimes the gneissic-granite shows bare, and at others elevated into sierras with slopes covered with Pampean formation.

Further south-west, and lying between the Tandil and Bahia Blanca, are the metamorphic sierras Phillahuinco, Ventana, and Curamalal, extending west and north-west, a total length of about 100 miles, nearly to Puan. In 1859, I spent a turbulent period of several months among these mountains, as a member of a commission charged to explore the south-western frontier of Buenos Ayres, which was then being raided by the Patagonian, Araucanian, and Pampa tribes of savages. Referring to my old field-book, I find evidences that some of my notes were made in a hurry.

The greatest bulk of the Ventana range appears to be gathered near the highest peak of the Curamalai section, the elevation of which, by trigonometric measurement, I found to be 3363 feet above sea-level, and the Ventana peak 3563 feet. The inclination of their strata is from $60^{\circ}$ to $85^{\circ}$, dipping, with little variation, to the north-east. On their south-west slopes, so far as we explored them, these mountains are composed of extremely hard quartz rock, white, pink, and other colours. In many places, it was cut into large rhomboidal-shaped solids. 
The highly calcareous, argillaceous rock-cap of the plain, which lies between the Ventana and Bahia Blanca, slopes west-south-west, its elevation at the southern foot of the Ventana range being about 500 feet, and at Nueva Roma about 230 feet, above sea-level.

Scattered over the surface of this plateau are many hollows, which, in some instances, are 100 feet below the general level. At their bottoms small lagoons are frequently found.

On the northern slope of the culminating peak of the Ventana, I found a conglomerate of rounded quartz pebbles, cemented by sandy, ferruginous matter. I have seen specimens of similar conglomerate from the north-west slope of the Curamalal range. I do not know the elevation of the bed which I found, but, for several reasons, believe it to be about 1200 feet above sea-level. It was, in great part, cemented to the quartz rock of the mountain, although masses of it, cubic yards in volume, had broken down or become displaced. Darwin states that, from 300 to 400 feet above the plain on the south side of the Ventana (estimated at 840 feet elevation by some Spanish officers), he "found a few small patches of conglomerate and breccia, firmly cemented by ferruginous matter to the abrupt and battered face of the quartz, traces being thus exhibited of ancient sea action." He thus estimates the height of that which he found on the south side of the mountain at, approximately, the same as that which I found on the north side.

Explorers differ as to the character and structure of the great belt of dunes which stretches along the coast from Cape San Antonio to Bahia Blanca. I am familiar with them for a distance of only 70 miles east of the latter place, along which extension they are massed to their greatest breadth and height. Perhaps an unpublished leaf from my note-book, of 1859 , will enable you to realize, what they are as I saw them :- "We proceeded to explore the course of the river Mostazas among the dunes. For 7 miles we forced our horses over sandhills and through marshes and lagoons, although they sunk to their knees at every step, and frequently floundered to their breasts, in the burrows of the tuco-tuco, the Ctenomys magellanica, about the size of a small rat. At last they lay down completely exhausted. Far to the east, we could still distinguish lagoons, but not a break in the coast-line gave indication of the outlet of the river, while all around us the bare sandhills reflected the sun with painful brilliancy. The exhausted condition of our horses obliged us to return dismounted. The dunes near the coast are composed of pure quartz sand of every colour, nearly all of it transiucent. As they extend towards the interior, they have a slight mixture of earth, until their inland line is found to contain a preponderance of light pulverized soil. Gradually a scanty vegetation appears, until, bordering the fertile lands, they are covered with coarse grass and a few stunted shrubs. Viewed from the north, they have an abrupt descent towards the west. Their coast-line is about 110 feet high on an average; but inland they are of every elevation, from 5 to 100 feet. The south-west gales violently agitate them, and cloud the air with their materials. Frequently, bowl-shaped excavations are found near their summits, which appear like works of art, so regularly are they scooped out by the wind, which must have been of terrific force. One of these, a detached hill of sand and dust, on the Sauce Grande river, about 12 miles from the coast, has had at least 5000 cubic yards of material thus taken out near its top. At the bottom of the excavation I found several fragments of quartz rock, like that on the southern slopes of the Sierra Ventana. In all the dunes composed of pure sand, I found, by digging 4 inches below their surface, on their sides or summits, that the sand was quite wet. Such was the case during our stay, although a very dry season. Numberless little lagoons, from 50 to 150 feet in diameter, with bottoms of soft mud, are 
scattered among them, around the margins of which grow rushes, weeds, and bunches of the exquisitely beautiful pampa-grass, the Gynerium argentium. Often, when the ponds were nearly dry, tho soft silky flowers of the pampa-grass had covered their muddy bottoms with a white mantle. Numerous aquatic birds are to be seen swimming in the shallow water of the open ones. Sporting with each other are nutrias (the South American otter, the Myapotamus Coypus), ducks, geese, black-necked swans, water-hens, and rose-coloured spoonbills, all so tame that I could sit on horseback within 20 feet of them without disturbing the amusements. I have counted fourteen otters in a small lagoon; and, from the apparent familiarity with which they rubbed noses with the ducks, they were as much a part of the family as any of the feathered tribe. I never molest them. It would be a pity to break in upon their Arcadia."

I have lingered among the Ventana mountains and in their vicinity, as they were once lofty islands which played an important rôle in arresting and protecting the Pampean mud.

Eastern Boundary of thie Basin.-Cuyabi at the head of the Paraguay river, is, according to numerous observations of Clauss, only 660 feet above sea-level. The valleys around it are bounded by vertical cliffs of red sandstone overlying argillaceous shales, which easily disintegrate. The Matto-grosso highlands, south of Cuyabá, as far as Paraguay, are practically unexplored; but I have no doubt they are of the same formation of sandstone and shales resting on metamorphic rocks.

The Apa river, which is the nortbern boundary of Paraguay, drains a limestone district. Bourgade says "the main framework of Paraguay is a dark-red sandstone, but basaltic formations may be seen in many parts. Immense areas are covered to a considerable depth by a fertile red earth representing the decomposition of the sandstone hills."

From Asuncion, the capital of Paraguay, south-east to the Apipe rapids of the river Paraná, the Cordillera of Caa-guazu throws off a range of hills which overlooks a great triangular space at the south-west corner of Paraguay, slightly elevated above the sea, and consisting of low sandy ground and morasses, at times flooded by the Paraguay river. This district, united to that of the Ybará lagoon, in northern Corrientes, was probably the delta of the Paraná when it emptied into the ancient Pampean sea. The river is charged with but little silt in comparison to its much smaller affluent the Paraguay; but in flood it carries a volume of water said to be ten times that of the latter stream, and its width, along the northern sandstone border of Corrientes, is from 3 to 9 miles. The alluvium, from the immense area of Brazil which it drains, is arrested by the rapids, reefs, and falls of its middle course, where it violently tears a deep channel through huge beds of red sandstone, to afterwards unite its yellowish waters with those of the muddy Paraguay.

Lying between the rivers Paraná and Uruguay is the Argentine Mesopotamia, the provinces of Corrientes and Entre Rios, covered with modern alluvium. The former is gently undulating, and is half drowned in lagoons, the largest being the famous Ybará. The south and south-western part of Entre Rios is composed extensively of argillaceous earth, and the whole State is traversed by ridges of low hills running nearly north and south, the main ones never exceeding an altitude of 650 feet above sea-level. The framework of the province is of sandstone, covered in some places by shell limestone, and sometimes by granular limestone. The north-eastern part is sandy, with numerous hillocks of siliceous gravel. The exposed sandstone, on the river Gualeguay, extends north almost to the Ybará lagoon. On the left bank of the river Paraná, just south of its junction with the Paraguay, is the town of Corrientes, built on a red sandstone bluff. The same stone shows 
for 30 miles down stream, where it disappears; and thence, for 240 miles the banks sometimes rising to a height of 80 feet, and then at Goya descending almost to the river-level, are composed of sandy clay ; but near Bella Vista are masses of rolled pebbles. Near the boundary-line of Corrientes and Entre Rios, the banks of the Paraná are very low on both sides of the river, and continue so for nearly 100 miles; but thence, southward, for 150 miles, the left bank is margined as far as Diamante by a range of hills from 125 to 160 feet high, at times boldly escarped and presenting a fine geological section. From Diamante the hills trend inland south-east about 50 miles, as far as Victoria; and they probably formed the border of an ancient channel of the river Paraná.

From Santa Fé to the head of the Plata estuary, the right bank of the Paraná shows a precipitous bluff of reddish clay, varying from 25 to 65 feet above mean river-level. It is being gradually undermined, and tumbles in great blocks into the river to add to its volume of silt.

The Uruguay river flows, almost throughout its course, over a rocky bed, mostly of red sandstone, at times very coarse, and then, again, of extremely fine composition; but below La Cruz, in Corrientes, there is much limestone, albeit the sandstone still predominates. The Uruguay is, except in flood, a clear-water stream, and, even at its highest level, carries comparatively but little silt.

I have ridden over much of the Banda Oriental del Uruguay. The southern and western half lies from 150 to 300 feet above sea-level. Darwin is correct in saying, "It has a gently undulatory surface, with a basis of primary rocks, and is in most parts covered up with an unstratified mass, of no great thickness, of reddish Pampean mud."

Secondary Rivers.-I refer again to the very important rivers Grande and Parapiti. Minchin says of them, "The Rio Grande drains a considerable part of South-Eastern Bolivia. It has its sources among the ranges bordering the tableland, and flows for some 400 miles through a deep, narrow gorge, and reaches the plains in lat. $18^{\circ} 55^{\prime}$. Bending north, it then describes a semicircle, and finally runs north-west to join the Mamoré. In its course across the plains, and as far north as lat. $17^{\circ} 30^{\prime}$, the river flows through a wide sandy bed, bounded by banks from 16 to 25 feet high. The Parapiti rises at an elevation of 2030 feet in lat. $19^{\circ} 59^{\prime} 18^{\prime \prime}$, long. $63^{\circ} 4^{\prime}$. At the close of the dry season it flows 65 cubic yards per second, and is then absorbed by the sandy region of the plain. In the wet season it runs through a well-defined bed as far as lat. $19^{\circ} 6^{\prime}$, long. $62^{\circ} 22^{\prime}$, and then spreads through the swampy, forest-covered plain. Its waters, again uniting, cut through the south range of Chiquitos at Qumome pass, and form Lake Concepcion."

Between $20^{\circ}$ and $30^{\circ} \mathrm{S}$. lat. the arid, Andean slopes collect and send southeastward, across the Gran Chaco, the waters of the three great rivers Pilcomayo, Bermejo, and Salado or Juramento. They are almost without an affluent once they leave the foot of the mountains, where they have their greatest volume. Sometimes they split into several channels, making narrow and enormous islands in the plain. They are all very crooked, and have uncertain beds, at times changing an old course for a new one miles distant. Thus they erode and tear away great quantities of Pampean material, dissolve it into silt, and pour it into the Paraguay and Paraná. Pelleschi, in his admirable work on the Gran Chaco, estimates that "the soil annually subtracted from the territory of the Chaco by the Bermejo alone, equals $6,400,000$ cubic yards."

The rivers Saladillo, Primero, and Segundo provide the water to meet the evaporation from the great inland lake of Porongos. The Tercero and Cuarto unite and enter the Paraná near Rosario, with a considerable volume of water. 
The Quinto, with other small rivers, draining the southern spurs of the Cordova range, are absorbed by the thirsty Pampean swamp, La Amarga.

Some of these rivers carry a large quantity of lime, and many of their westerly affluents carry so much as to have a white colour, thus accounting for the considerable number of them called " Rio Blanco."

A large river system, having many ramifications in the provinces of La Rioja, Mendoza, and San Luis, gathers into lagoons and main channels to find its way to Lake Urre Lauquen, and, in floods, to the Colorado. Physical and climatic changes, of which I shall treat, have profoundly modified this section of the Argentine Republic, and reduced the volume of its waters.

I am indebted to several of the Argentine railway companies for sections of their lines, made from instrumental surveys. From these, and from other sources, including a carefully prepared table of altitudes by the Argentine engineer, A. Schneidewind, I have had plotted the sections which accompany this address.

Sections of the Country.-Section 1 shows a part of the coast-line of the Southern railway. It is practically a cross-section of the east coast of the province of Buenos Ayres from north to south, where the lowest part of the Pampean beds slopes into the ocean. It passes also near the head of Samborombon bay, which was once a great muddy estuary extending far inland, and the home of countless myriads of small crabs. The land slope of this bay so gradually merges into the ocean that, at a little distance, it is difficult to tell where the shore-line meets the water. Century by century, it now slowly advances seaward.

Section 2, from Buenos Ayres to Rosario and Tucuman, shows with what regularity the country rises, from south-east to north-west, up to the outlying foothills of the Andes.

Section 3 is the first 350 kilometres of the Neuquen extension of the Southern railway, and shows in part the relation of the Colorado to the Rio Negro.

Section 4 is the Buenos Ayres and Pacific railway to Villa Mercedes, and thence to Mendoza by the Argentine Great Western. Here we have a line almost on a parallel of latitude nearly to the frontier of Chile. Again we note the regular slope of the Pampa westward, until the country begins to swell into the Cordova sierra. Thence to Mendoza it is broken.

Section 5 shows the Bahia Blanca and North-Western Railway, as far as Toay, and thence its proposed extension to Villa Mercedes. It traverses a district, the southern half of which bas apparently been much troubled in former times by water, wind, and sand. From Victoria to Villa Mercedes the country assumes a more uniform slope; but, beyond that, to the north, it rapidly rises into the barren, mountainous districts of San Luis and Western Cordova.

Section 6 is the Central Argentine railway, Rosario to Cordova. This is of interest as showing how far the uplifting of the Cordova range extended east, and nearly divided the Pampean sea into a great northern and southern section. In fact, this railway is the southern border of a belt of rounded-up country, extending from the Cordova sierra to within 30 to 40 miles of the river Paraná.

Section 7 is from Bahia Blanca north to Villa Maria (say 482 miles), thence to Cordova by the Central Argentine line, thence to Tucuman by the Central Northern section of the Cordova Central railway, and thence to Jujuy by the Government railway-a total length, nearly south to north, of, say, 1127 miles. This section presents some notable features : between Bahia Blanca and Carhué it crosses the extreme western slope of the Curamalal sierra; thence to Villa Maria it shows an almost level stretch of Pampa, the lowest part of which, near Trenque 
Lauquen, is only about 300 feet above sea-level. This depression is on the parallel of Samborombon bay, down to which it gradually slopes in a distance of 300 miles. From Villa Maria to Dean Funes the line ascends the Cordova mountains, a marked feature of which is their bold western escarpment, overlooking the profound hollow which separates them from the south-eastern spur of the Catamarca sierras. In this depression lies the Salina Grande. From Tucuman to Jujuy, near the Bolivian frontier, the country rises rapidly towards that mountain bastion which is thrown so far east from the Pacific Ocean, and which is the true heart of the Andes. During a ride from Jujuy to Potosi, I could not avoid being impressed with this mighty swelling up of the continent; and on several occasions, especially looking eastward, I was convinced that I could see the curvature of our globe.

Section 8 is the Buenos Ayres Western Railway. It stretches south-west across the heart of the true Pampean plain. The regularity of its gentle slope is remarkable.

Section 9 shows one of the lines of the Southern railway, from Buenos Ayres to Bahia Blanca, and the gradual rise of the country south-westward, up the slope of the Curamalal mountains.

Section 10. This is of great interest. It starts at the Atlantic coast, and is roughly parallel to, and south-west and west of, the Plata estuary and Paraná river, and from 70 to 100 miles distant from them, until reaching a point about 100 miles above the mouth of the river Pilcomayo; thence to the great gap, between the Bolivian Andes and the Chiquitos sierras, and thence to the lip of the first fall of the river Madeira-a total length of about 1770 geographical miles (about 3300 kilometres). This line, from the great gap to the Atlantic coast, was approximately that of least resistance to the flow of the Pampean mud. I have called attention to the very gradual north-eastern swell due to the Cordova sierra. This section clearly shows it, and indicates, moreover, that the Salado, or Juramento, river flows along its lowest margin, and serves as the boundary of the most southern part of the Gran Chaco. In fact, the Salado occupies the southwest side of a very level depression, 300 miles across, and only 240 feet above the sea, along the north-eastern edge of which runs the Bermejo. The northern undefined limit of the Gran Chaco is probably the Chiquitos sierras. From the Bermejo, northward, the section shows the slope of this Chaco district. It is the natural incline which the waters gave it as the sand was poured in from the north.

I have been obliged to estimate the height of the present water-divide between the Plata valley and the Mojos basin. For the first 240 miles north of the divide I allow a slope of 9 inches to the geographical mile, and thence down the Mamoré river to the present lip of the Madeira falls, a descent of about 4 inches to the mile. Like Keller, I found the Mamoré to be a very sluggish stream, "the inclination very small." Barometric measurements I could not take, owing to the failure of some instruments and the loss of others. The height of the upper fall of the Madeira is shown to be $\mathbf{5 4 7}$ feet above the sea. It has served as my startingpoint in estimating the summit of the water-divide at 817 feet. Minchin gives a few widely separated barometric measurements on his map of the neighbouring country to the east, and I judge that he makes the divide perhaps 100 feet higher than I do. I should be glad if so able an engineer would give us further information about it.

Formation of the Bed of the Pampean Sea.-A vast area of the Plata valley is covered, to a depth of from 20 to 100 feet, by a bed of reddish-yellow, semiplastic, argillaceous earth, varying in colour, hardness, and constituent parts. It is mixed with a little sand, and has traces of titanic iron and olivine. Due probably 
to underground percolation from the lime-carrying rivers, it frequently merges into a marly rock full of calcareous nodules. This rock is found over immense areas of the country, and is at times apparently stratified. Great numbers of the Calomys Biscacha burrow in families under the rocky caps which are near the surface, and thus expose them to view. "For this reason," according to Heusser and Claraz, "the Pampa Indians call the hard material 'trui-cura,' or Biscacha stone (trui, Biscacha; and cura, stone); but the country people have given it the name of tosca, of which the literal translation is tufa, whether it be the bed itself or the calcareous nodules contained in the clay. The Pampas are entirely without stones or pebbles. In general the Pampa clay becomes more and more sandy as one goes west. It is the same towards the south, starting from the Quejen Salado. There is much gypsum and carbonate of lime in the deposits, and much fine débris of a volcanic nature."

In 1859 , in a small cave excavated under a tosca cap at Nueva Roma, northwest of Bahia Blanca, I found stalactites from 6 to 12 inches long. Pelleschi tells me that at Puan, where a small stream has cut out a bowl-shaped depression (785 feet elevation above the sea by instrumental survey), there is a cap of tosca covering the district which is well filled with shells, closely cemented, but he does not know the species; and that, on an inland in a neighbouring lagoon, excellent lime is made from a limestone rock found there.

A broad saddle of Pampean formation lies at an elevation of over 600 feet between the Ventana and Tandil ranges. The tosca rock is almost everywhere en évidence in the sloping plain which surrounds the Ventana and Curamalal ranges, and it is extensively exposed in the banks, and at the rapids and falls in all the little streams. I have noticed that, where these run over tosca, it has a hardened surface for a depth of perhaps half an inch. This is due to the hydraulic properties of the rock, which have in places been found so marked, notably at Rosario, in Santa Fé, that a fow years ago, Carrasco states, the beds were worked for the manufacture of hydraulic cement.

D'Orbigny, Darwin, Bravard, Sir Woodbine Parish, Weddell, Heusser and Claraz, and others, disagree as to the origin of the "Pampean mud." Darwin wisely said, "it poured down from the north;" but the then paucity of geographical knowledge regarding the interior of South America did not enable him to fix its exact source and method of conveyance. Embedded in the Pampean formation, over widely extended areas, have been found the fossil remains of the mastodon, megatherium, mylodon, and other gigantic animals, those from Rosario to the south being mixed with shells of species still living in the neighbouring seas. After the Pampean beds were formed, and their southern and eastern margin began to emerge from the waters, the ocean along the shallow coast rolled up on the gently inclined plain quantities of shells, banks of which, miles in length, may be seen to-day far inland, giving evidences, by their curvature and general appearance, of having been piled up along an ancient coast-line.

Not far from Bahia Blanca I have ridden for miles along the top of one of these embankments, about 20 feet high, and 100 feet wide at the base. Most of the shells had been broken by wave-action, and were mixed with abundance of rounded pumice, which probably floated down the Colorado and Negro from some volcanic centre of the distant Andes.

But a portion of the Pampean formation is still submerged, for tosca rock may be found throughout the length of the Plata estuary forming the bottom of its s outhern half. Thence it extends its eastern and southern margin under water, along the coast of Buenos Ayres, at least as far as Bahia Blanca.

The savants whom I have named have presented us with abundant evidences 
that the whole Pampean formation was once submerged. What appears to have confused them is the finding of similar beds in widely separated localities, and at elevations varying by thousands of feet. One may believe that wherever, in the immense drainage area of the ancient Plata basin, the conditions of rivers, lakes, and inland seas were favourable to the distribution of silt from the mud-producing rocks which margin the entire basin in such prodigious quantities, there the "mud" should be found; and it is conceivable that even to-day, if Nature were to form a lake by throwing a permanent dam across the entrance to an extensive valley leading into that basin, the streams entering it would there deposit Pampean mud. If this be true, there is no reason why such mud should not be found resting immediately on crystalline rocks in places. The extent of any continuous bed would alone be limited by the drainage area receiving the silt. The origin and age of a deposit, wherever found, be it at sea-level or 12,000 feet above, or be it a square mile in area or 100,000 square miles, should be treated upon its individual merits. Darwin alone appears to have entertained doubts as to the contemporaneous origin of all materials similar to the Pampean beds, attributing their uniformity more to " the similarity of the rocky framework of the continent."

The Pampean sea connected with the Atlantic ocean between Uruguay and the Tandil Sierra. It was probably about 1400 miles in length, with an average width of above 400 miles. Roughly estimated, its area must have been about 600,000 square miles-say about two-thirds the size of the Mediterranean sea. The area of the ancient Mojos lake was about 115,000 square miles, being seven-tenths that of the Black sea, and exceeding that of the five "Great Lakes" of North America, which is 93,581 square miles. The relation of the Pampean sea to the Mojos lake was similar to that of the Mediterranean to the Black sea. Traces of it are still observable, notably the great, low, flooded morass of Xarayas on the upper Paraguay river, and the ancient delta of the Paraná, including the Ybará lagoon. The Salina Grande was also an arm of it-a great inland fiord. The sea, moreover, must have covered large areas of Paraguay, Corrientes, Entre Rios, and Uruguay, and, before the uplifting of the country, it extended south-west to the rivers Chadi-Leofu and the Colorado, lapping round the southern slope of the Ventana range until the curved rim, concave to the north-east, which connects this with the Sierra de Cordova, was sufficiently elevated to completely cut off its south-western extension. This rim, for the first 50 miles, starting at the Ventana, is about 700 to 750 feet above the sea, and shows much tosca rock near the surface. It afterwards rises rapidly towards the Cordova sierra.

The Uplifting of the Pampean Beds.-The Pampean beds were apparently laid down in shallow water. Their present irregularity and elevation may be attributed to pronounced local uplifting, followed by an extremely slow general upheaval of the Andes from west to east, which was communicated to the whole bed of the Pampean sea, raising it ultimately to its present level. Gradually, as the Ventana, Tandil, and Cordova sierras were lifted, the mud settled upon their slopes until they ceased to exist as lofty islands, and with their connecting-rim of high ground formed a vast breakwater against any inroad of the ocean from the south or south-west. South of latitude $30^{\circ}$ the force which raised the Andes has not shown the same vigour which it has to the north of that parallel, where it appears to have been greater in proportion to the broadening and swelling up of the mountain masses. As a resultant of this and its slope to the eastward, the northern section seems to be upheaved from the north-west, while, southward of lat. $30^{\circ}$, the real west-to-east action is apparent. Here the great distance of the Atlantic coast from the Andes has caused the eastern part of the province of Buenos Ayres to be raise 1 but little, not sufficiently to lift the Pampean beds 
entirely out of the sea. In the north the gradually decreasing distance between the Cordillera and the Brazilian highlands confined the force and gave the plain its maximum lift at the great gap, at about $18^{\circ}$ lat., where the leverage of the Andes must then have ceased, due to the fact that, at this point, they take a sharp turn to the north-west, leaving the basin of the Beni and Mojos undisturbed.

This local and general upheaval determined the course of the Paraguay, the lower Paraná, and the Plata rivers, which were naturally pushed over against the more ancient Brazilian formation. It also, as the Pampean sea retired, caused the Pilcomayo and Bermejo to take their south-east course across the Gran Chaco and find their present outlet.

The Cordova range has lifted the Pampean mud to an elevation of about 1300 feet above sea-level.

The Tandil range has brought up, to a height of 900 feet, beds identical with the Tertiary deposits 100 feet below the surface at Buenos Ayres. This indicates an upheaval of 1000 feet since Tertiary times.

Lying between the Bermejo river and the Salado, say the southern third of the Gran Chaco, we appear to have an almost undisturbed part of the bottom of the ancient sea-the present boundary belt between northern and southern climatic influences.

Age of the Pampean Formation.-The United States engineers, Humphreys and Abbot, estimate the amount of silt discharged yearly by the Mississippi river to be one cubic mile in twenty-two years. Although it carries, per cubic foot of water, much more silt than the Plata, I doubt if it exceeds that of the river Madeira, which now drains the Mojos basin, and is a very turbid stream.

The mean flow of the Mississippi at New Orleans is 675,000 cubic feet per second, but its maximum at flood is about $1,000,000$. The minimum flow of the Plata, past Buenos Ayres, is 534,000, the maximum 2,145,000. It may, therefore, be fairly assumed that the yearly flow of the great North American river is not superior, and may be inferior, to that of the Plata; and if it be admitted, as I believe, that the Madeira branch of the Amazon, at the falls, annually carries an amount of water equal to that passing Buenos Ayres, it will be evident that the total cubic volume of the streams which poured into the Pampean sea must have been equal to twice that which the modern Mississippi contributes to the Gulf of Mexico.

Estimating the Pampean mud to cover an area of 400,000 square miles, with an average thickness of 50 feet, it would represent about 4000 cubic miles of silt. The Andean and Brazilian shales and sandstones were probably disintegrated and dissolved with great rapidity when the rivers which tore them down flowed into the Pampean sea. These streams must then have carried, one with another, a quantity of silt which, compared to that carried to-day by the Plata and Madeira rivers, may safely be estimated at three-fourths the amount per cubic foot of water now carried by the Mississippi river. Allowing for partial loss of silt in the ocean, and from other causes, this would give the Pampean formation an age of about seventy thousand years.

How the Ancient Mojos Lake was formed.-I find the divortium aquarum between the Mojos and Plata basin to be only about 170 feet higher than the ancient lip of Guajará-mirim. It is easy to understand that the Rio Grande and the Parapiti have deposited there a quantity of alluvium far exceeding 170 feet in depth. The divide, prior to this and to the general uplifting movement described, could not have been more than 200 to 300 feet above sea-level, and thus much lower than even the present lip of the upper fall of the Madeira. Therefore through this southern gap the combined streams which now form the principal affluent of the river Amazon found their way. Slowly the highly charged, 
yellowish-brown waters sifted out and spread their heavier material over the sandy slope at the head of the Pampean sea, leaving the fine silt in suspension to be precipitated over the submerged plains. The waters from the north were augmented in turn by the Paraguay and Paraná, the Pilcomayo, Bermejo, and Salado. From east and west numerous rivers pushed into the sea, stirring up its waters, and thus keeping the greater part of the silt in suspension to be carried far southwards and deposited, principally, and in naximum thickness, over the Pampean region south of lat. $30^{\circ}$.

The Grande and the Parapiti entered the plain with a northern trend to contest with the great river of the north the possession of the gap. They struck it almost at a right angle, and slowly pushed their rival eastward over against the Chaco base of the Chiquitos sierras. Here the final conflict must have taken place, as the Grande and Parapiti threw their dam across the outlet of the Mojos river, thus cutting off its exit in to the ancient sea. No doubt the giant stream waged fierce war for thousands of years to keep its channel open, alternately sweeping away the barrier and again yielding to the ceaseless volume of sand and clay which, visible to-day, confirms the victory of the Grande and Parapiti. The dam having finally become permanent, the formation of the ancient Mojos lake was assured (see physical map). When it reached the level of the lip of Guajará-mirim, its waters commenced to tumble over it and carve their way to the Amazon. Since then huge volumes of alluvium have poured down the northern slopes of the Bolivian Andes; the ancient lake is now almost loaded with material, but is not yet entirely obliterated. The muddy silt which covers the surface of the basin is so fine that, when an Indian goes up-stream to the mountains, his friends ask him to bring back a stone that they may see what it is like.

Since forming the dam, the Rio Grande has slowly been returning westward down the counterslope which its own alluvium creates.

Slight Tidal Action of the Pampean Sea.-Off the mouth of the Rio de la Plata, the tides which flow south along the Brazilian coast meet those making north from the coast of Patagonia, counterbalance each other, and maintain the liquid mass at nearly the same level, so that the average tide at Montevideo is only about 3 feet. Thus the Plata river is able to pile its silt in a direct line further seaward than either the Orinoco or the Amazon. I have shown that the Ventana range acted as a massive breakwater to the Pampean sea, and that the Cordova sierra almost divided this into a northern and southern half. Hence the prevailing conditions appear to have permitted but little tidal action in the great basin. Had it been otherwise, as, à priori, one might suppose, the fierce contests which the tides would have waged when meeting the large rivers would have ripped up the Pampean beds and washed them into the ocean, and, in their place, we should now find nothing but a clayey, sandy, and shingle-covered waste.

In 1860 I located the northern railway from Buenos Ayres to San Fernando. An extremely violent “ Santa Rosa gale" swept up the Plata estuary. Finding by actual measurement that when its waters drove against the outflow of the Paraná river they tore 17 feet in one day into the high tosca bluff of San Isidro, I carried the definitive location over the hill instead of round the point at river-level.

The Inter-Andean Region.-The eastern inland Cordillera of the Andes which overlooks the Gran Chaco is separated from the Pacific coast range by a desert, bare, and almost waterless belt of mountainous lands, from 250 to 300 miles wide, through the heart of which I have ridden. An extraordinary parallelism exists between the numerous lines of sierras, mostly running north and south, which fill the space. Between them are deep, scooped-out depressions, sometimes containing salt lagoons. On the rare occasions of violent storms, these receive torrential 
streams from channels which ordinarily carry but little water, and many of which are dry for most of the year. The whole district appears to be a southern prolongation of the Titicaca basin, and possibly may have been so before the Andes reached their present elevation. As it extends southward it grows lower and less broken, and the salinas occupy a larger area until, to the west and north-west of the Sierra de Cordova, they are of enormous extent; but as latitude $30^{\circ}$ is passed, the eastern slope of the now narrow Andean chain begins to receive a sufficiently increased rainfall to supply the waters for the western system of Argentine rivers which try to find their way southward to the river Colorado, but which they only reach at rare intervals, when some exceptionally heavy storm aids their effort to satiate the sandy, thirsty desert which they traverse. This area of about 250,000 square miles (not a very comfortable country to march an army across) frequently presents evidences of marine action on a grand scale. D'Orbigny, Darwin, De Moussy, and Burmeister allude to the accumulations of rolled shingle found in the valleys and at the base of the mountains. Darwin speaks of the ocean as having "long acted at the foot of the eastern Cordillera at nearly the same level as on the basin plains of Chile, and that the origin and transportal of these vast beds of pebbles is an interesting problem." Perhaps a thorough study may show that the Patagonian gravel beds-76,000 square miles in area and 50 feet average thickness-were, like the Pampean deposits, in great part derived from the north. For reasons which I shall explain, I believe that all of this terribly eroded, inter-Andean district once had an abundant rainfall, and that, after the heavy material from the mountains had been sorted out, the rivers carried to the plains, to the west of the present province of Buenos Ayres, immense quantities of sand and clay derived from the masses of gneiss, schists, sandstone, and calcareous rock through which they flowed. For this reason, to the west of the curved boundary-line of the Pampear. beds, between the Ventana and Cordova sierras, the lands are dry, sandy, and uninviting.

The contour-lines of the country around the lower Colorado appears to indicate that the river once emptied into a broad, shallow estuary, which penetrated inland from the present coast-line about 116 miles. Over its bottom the Colorado dropped its silt, similar to the Pampean mud, but more siliceous. On what was once its northern shore, it is not surprising that Darwin should find "an accumulation of high sand-dunes, ranging westward from the coast twenty miles distant," and which he believed "were formed on the shores of an estuary." It probably included the present Bahia Blanca and its coast-line as far as Mount Hermoso, to the east of Punta Alta, where Darwin found so many fossil remains of gigantic mammifers. May we not suppose that these came from the north, were floated down the Colorado, and taken to this point by the northern currents which swept along the Patagonian coast?

Climatic Influences.-It must be admitted that an ancient sea two-thirds the size of the Mediterranean, and a lake much larger than the total area of the "Great Lakes" of North America, must have profoundly affected the climatic conditions of the adjoining regions. Perhaps no part of the world presented an example where the forces of Nature had an opportunity to display their power in equal magnitude, over such a continuous area, and with such uninterrupted simplicity. To the west, the Andes served as a lofty condenser, which, for a distance of over 2500 miles, guided the cold polar currents towards the equator and safeguarded their vigour. Similarly, the Brazilian highlands largely confined them to the great valley as they swept northward to do battle, in the heart of South America, with the warm vapours generated from the Pampean sea and ancient lake, and the steaming, tropical basin of the Amazon. The extensio 1 of the vapour 
belt southward towards the Atlantic ocean carried the equatorial currents nearer to the polar ones, thus inviting frequent atmospheric disturbances and resultant storm action. As the hot, vapour-laden winds, fertile in elements and force, met the southern cold ones, a prodigious amount of heat was set free by coudensation. Into the vacuum thus created the opposing currents rushed with ever-increasing rivalry, enlarging the area of mechanical action, condensation, and vacuum, and augmenting the violence of the storm-waters, which, sweeping along the mountain slopes, must have rapidly disintegrated and eroded them, and have acted as a potent agent to transport to their base much of the material from which the Pampean beds were sifted. The rainfall over the inter-Andean region must have produced many large lakes similar to Lake Titicaca, and a great river system, which, tributary to the Colorado, swelled it into a stream of the first rank, pouring into it the sand and silt which have completely filled the enormous estuary, the outline of which is still traceable.

One may believe that an increased rainfall gave a luxuriant vegetation, where herds of gigantic mammalia found feeding-ground; from which, from time to time, they were swept, by storm or swollen river, into the Pampean sea, where also they may have lost their lives in other ways, their remains being distributed over it by the currents.

To a minor degree the ancient sea and lake must have affected the inter-Andean climate, from Cuzco to the south, throughout the lacustrine basin of Titicaca, giving it greater rainfall and fertility than it now has. Geological examinations show that Titicaca was once one of the large lakes of the world, and that it has slowly been drying up. Does its gradual diminution date from the disappearance of the Pampean sea and Mojos lake?

Savage man may have lived in South America on the mountain slopes round the ancient sea. If so, he possibly hunted the mastodon, the megatherium, and numerous other of the gigantic fauna which probably were co-existent with him. His only highway, between the eastern and western halves of the continent, must have crossed the elevated region at the head of the Pampean sea, lying between $17^{\circ}$ and $19^{\circ} \mathrm{S}$. lat., which is still the only route in use for communication by land between Bolivia and Matto-grosse.

\section{A GREAT GLOBE.*}

\section{By Professor ÉLISÉE RECLUS.}

RECENTLY being in conversation here in London with a traveller and discoverer, I mentioned the great geographical importance of accurate representations of our planet in the shape of globes; suddenly he interrupted me, and said with a smile, "What is the use of your Lilliputian globes, ten, a hundred, or a thousand yards thick, when you have the very globe itself, our good and beneficent Earth, to walk over, to look at, to study, and to love?" Of course I laughed, and thought with him that all representations and symbols of life are very little in comparison with life itself : our works are small when contrasted with nature. But the great man who thus spoke in joke knew as well as I do, the value of scrupulous effects in geographical work. He has himself drawn very useful maps, which enable us to follow him in his great travels. We cannot all perambulate the surface of our planet, but we may still be very useful in a secondary way. The great question is to know in what direction

* Paper read at the Royal Geographical Society, June 27, 1898.

No. IV.-OCTOBER, 1898.] 


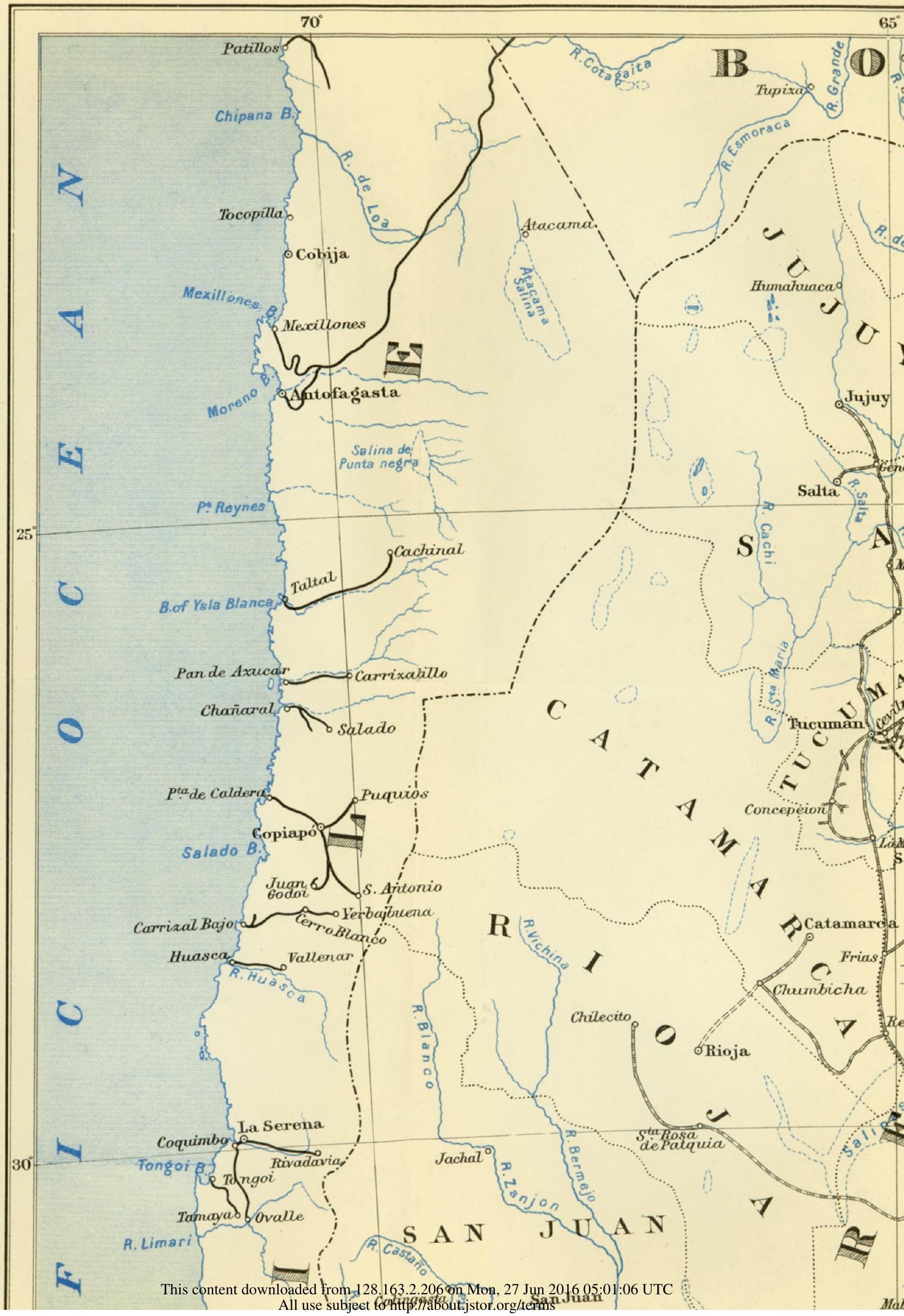




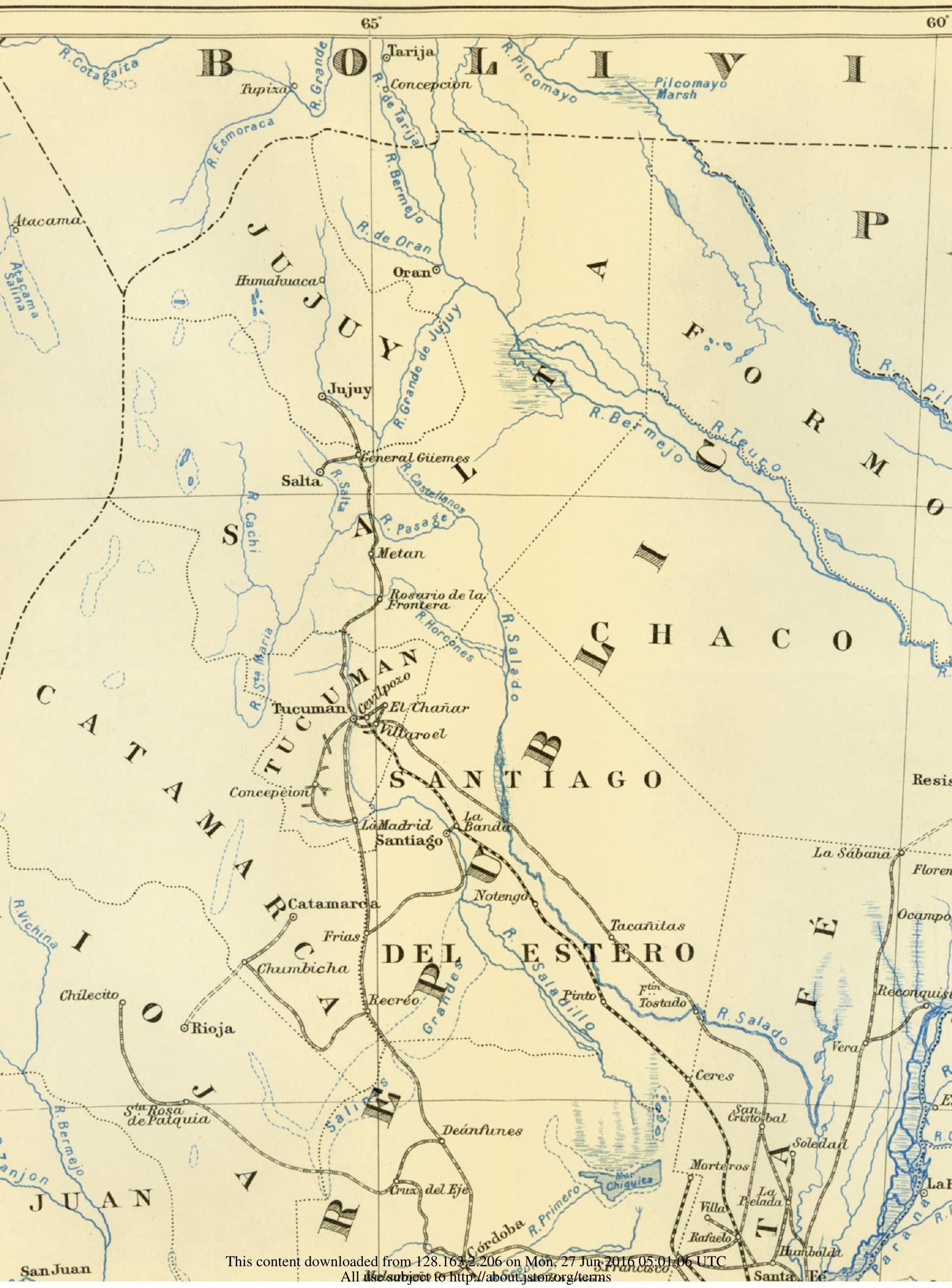




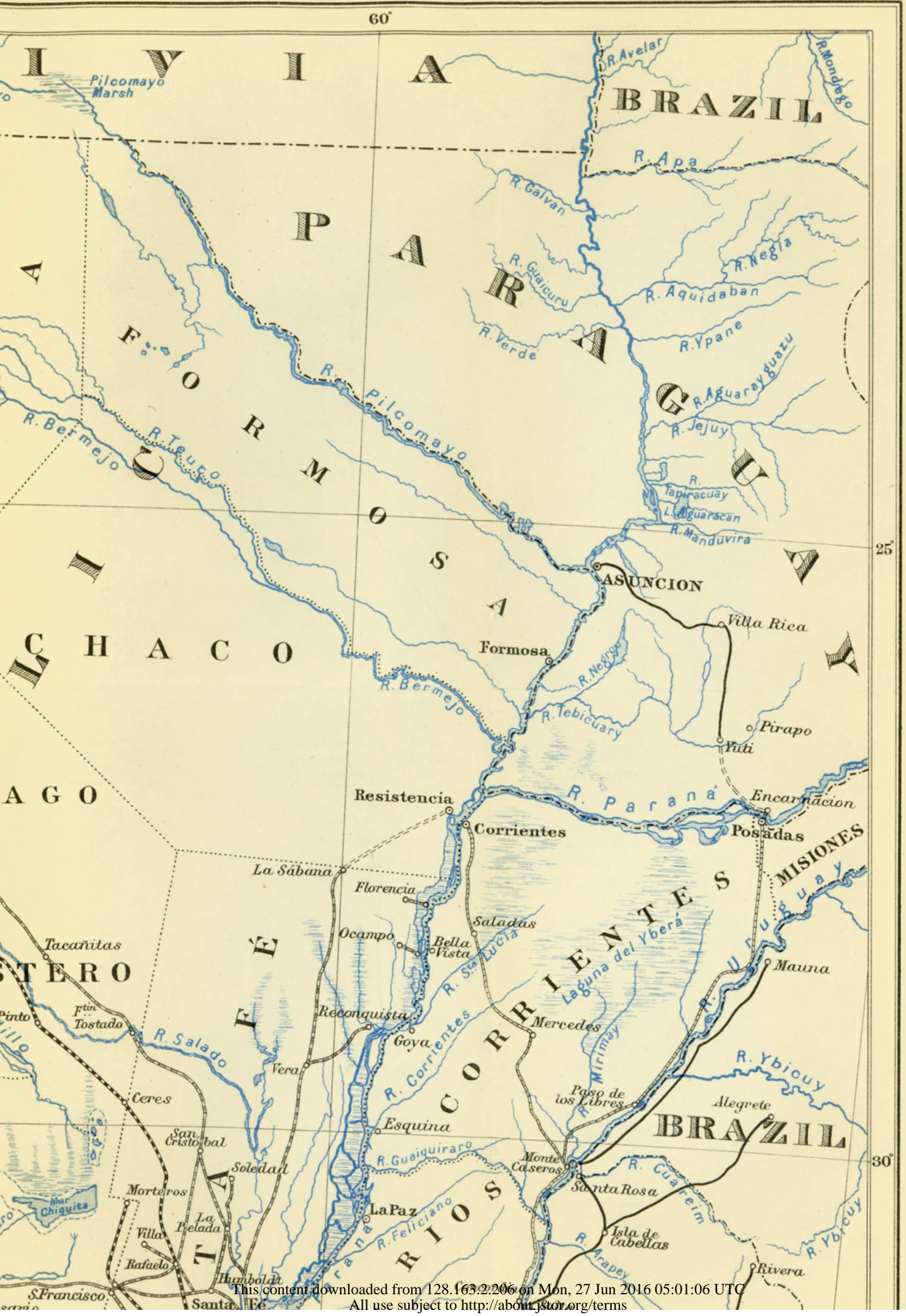


$\begin{array}{lll}A & C & 0\end{array}$

iriof: $\quad$ Formosa

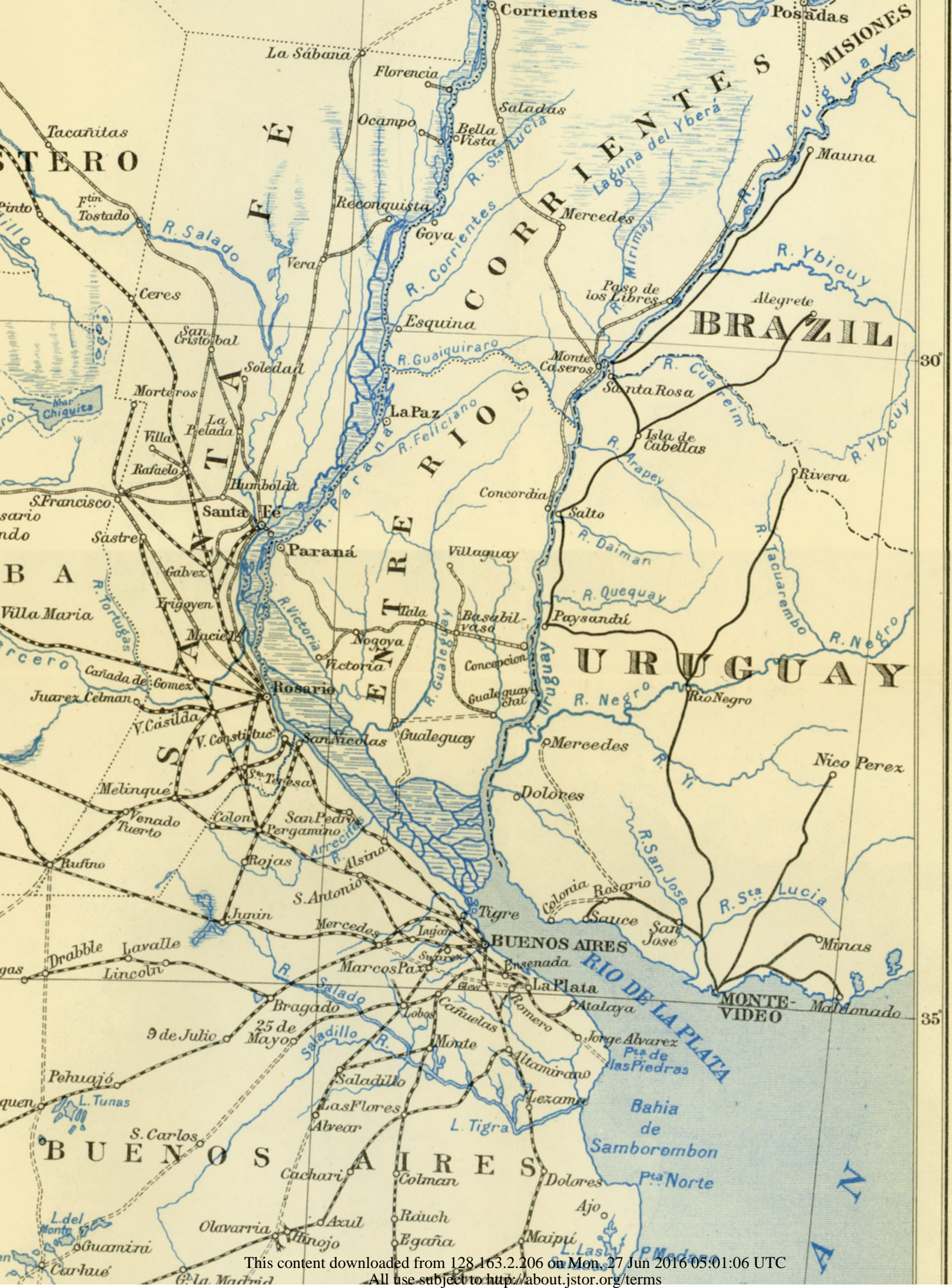




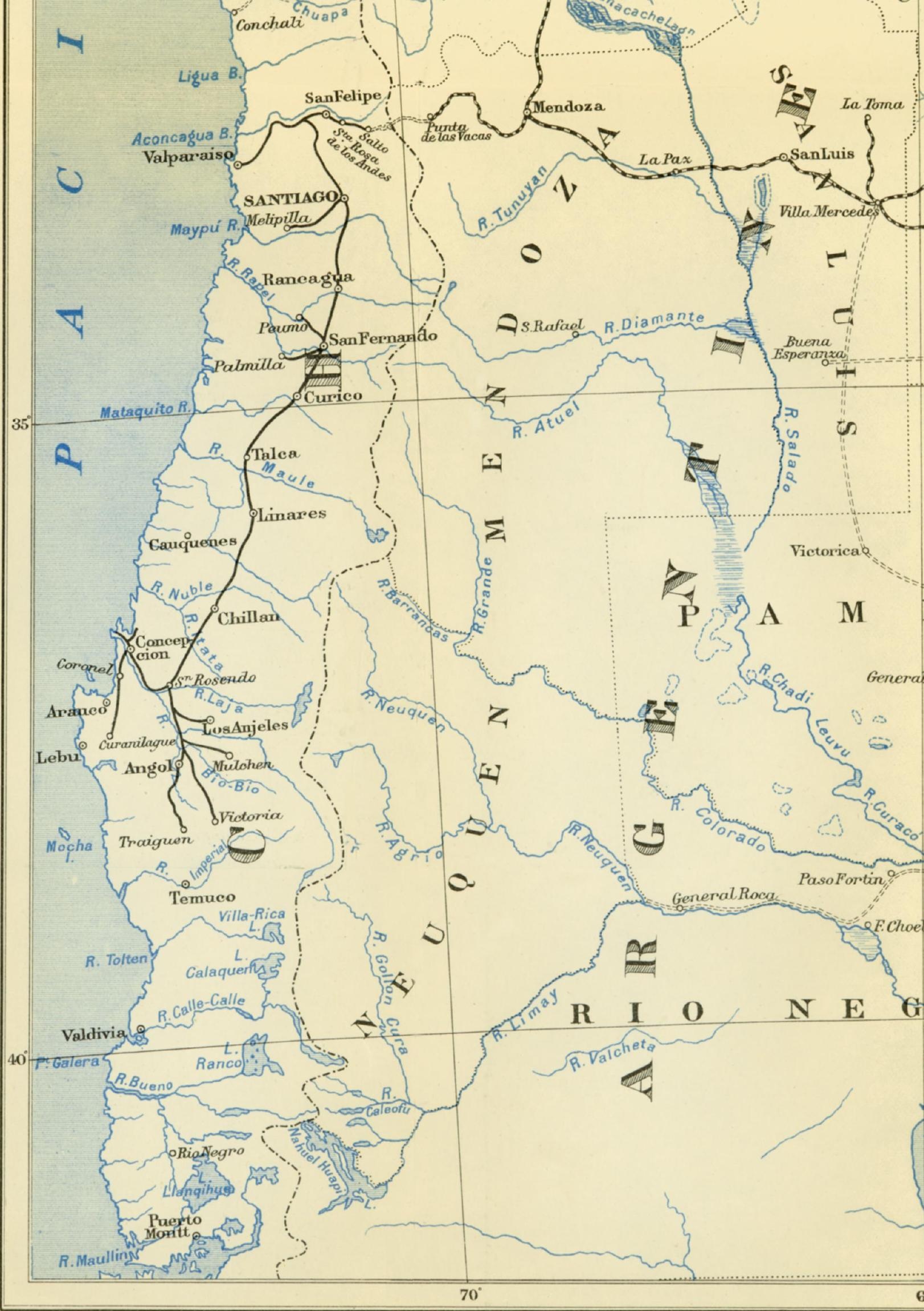

Published 


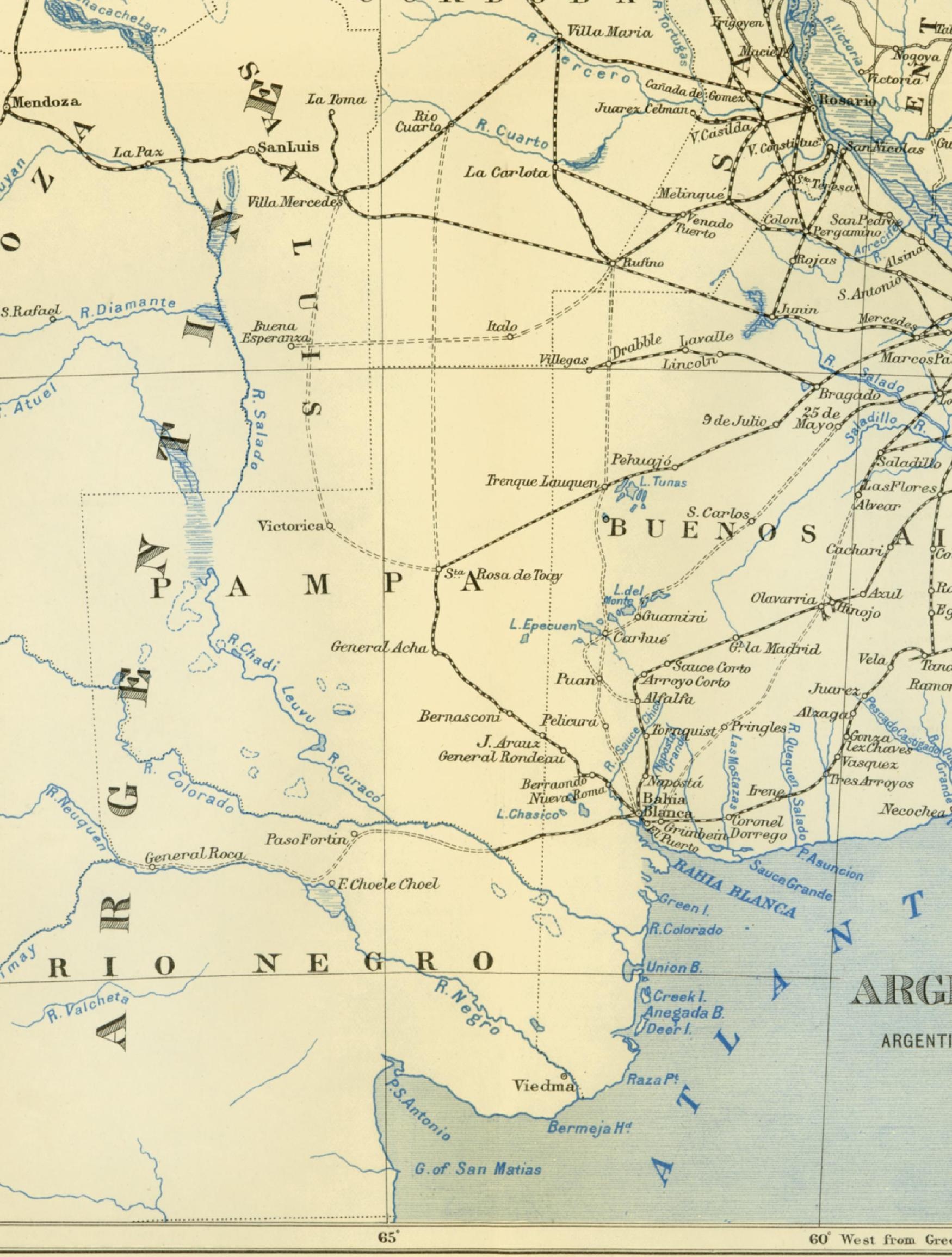

Published by the Royal Geographical Society 


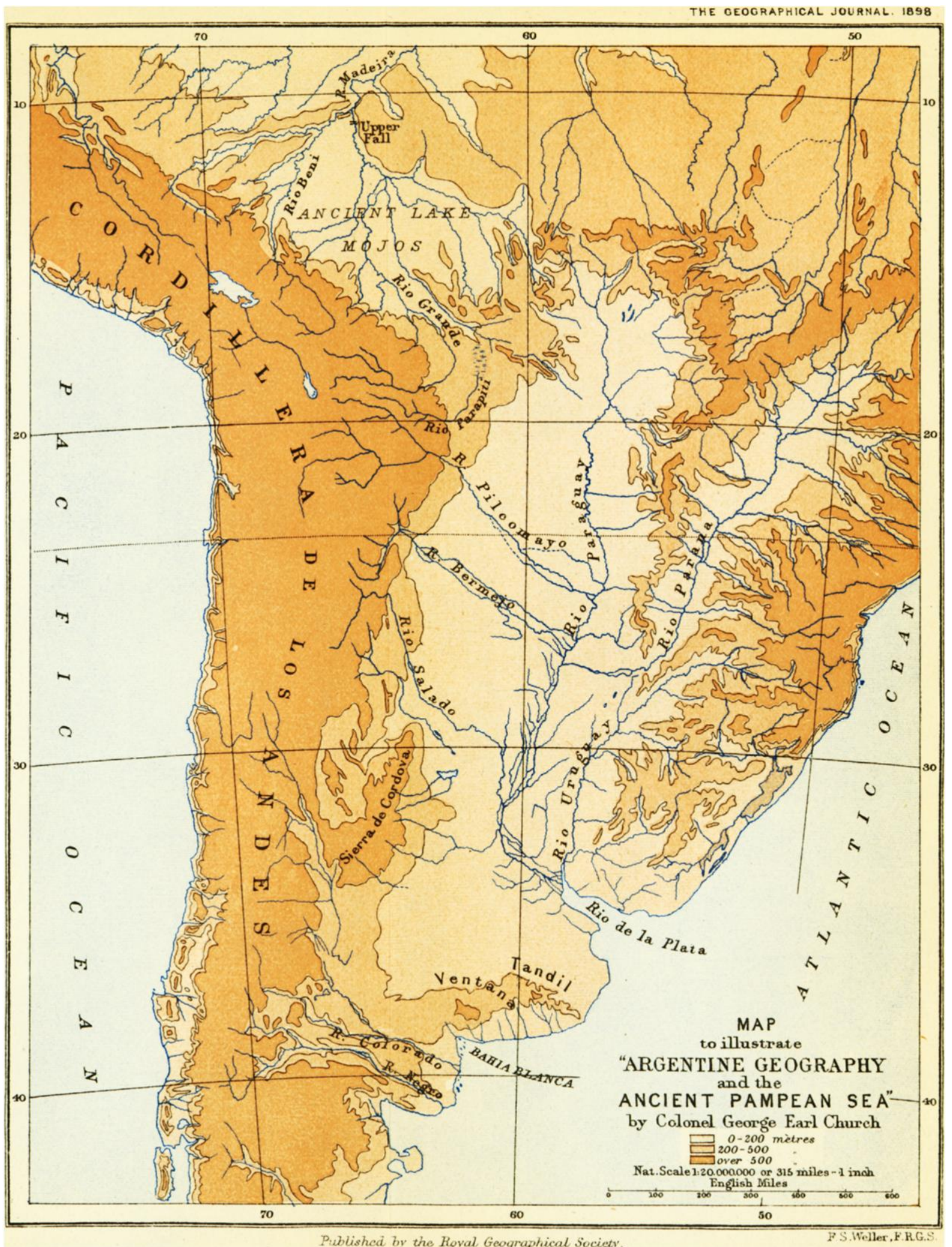



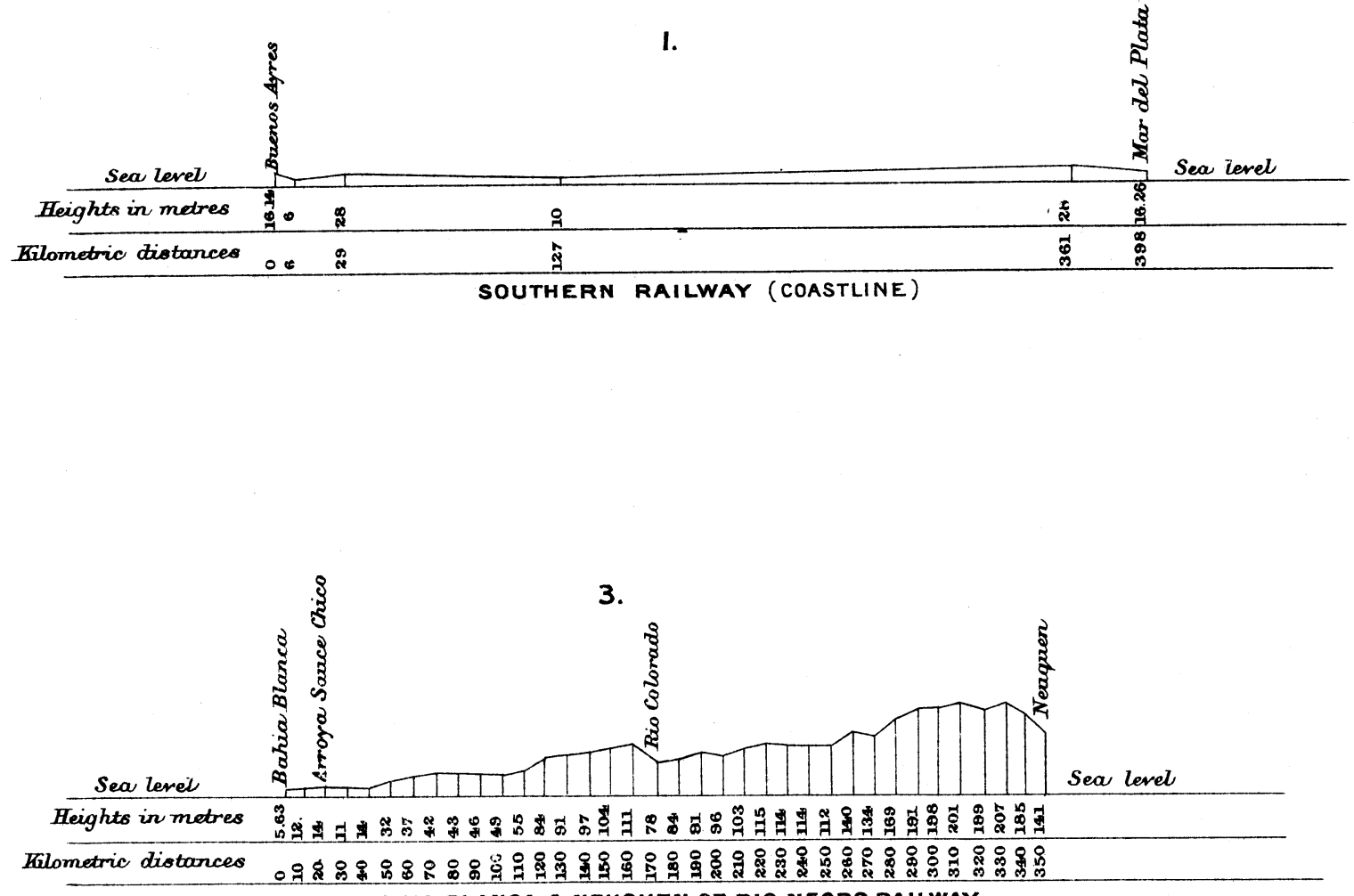

BAHIA BLANCA \& NEUQUEN OR RIO NEGRO RAILWAY.

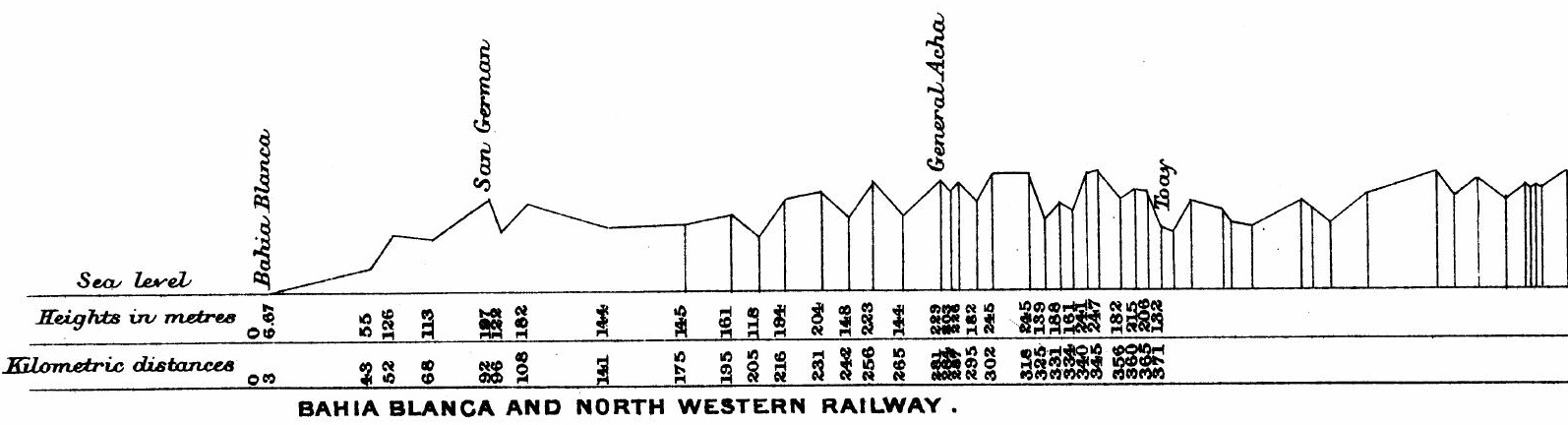




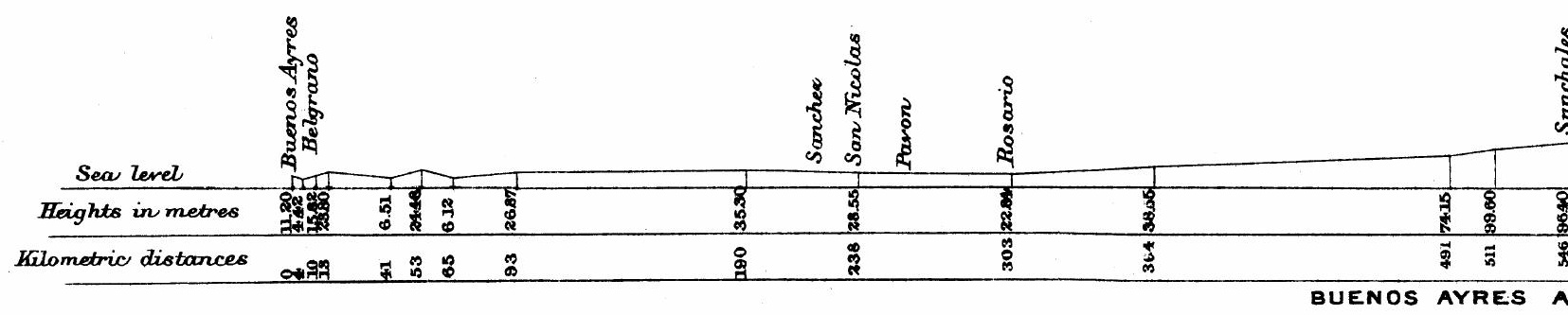

4.

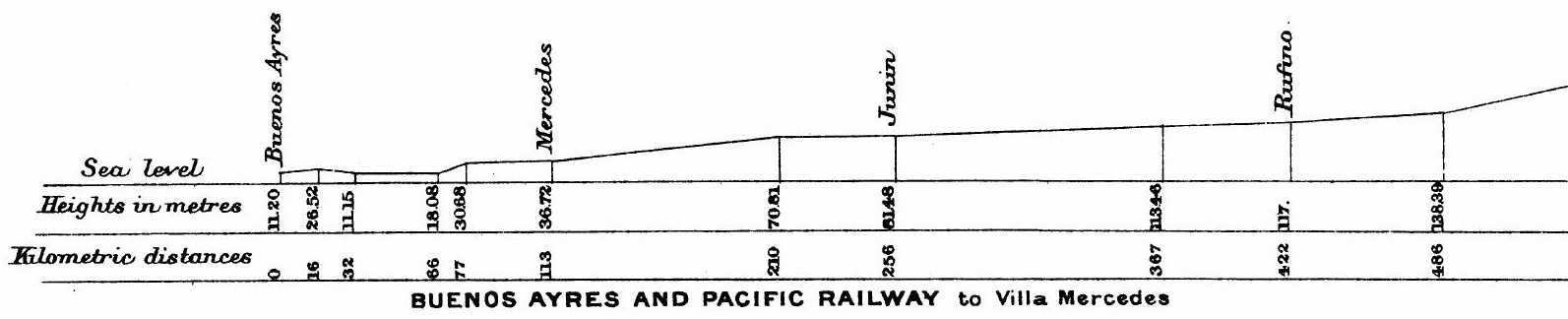

5.

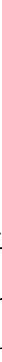

TOAY - VILLA MERCEDES RAILWAY .

Horizontal Scale, 1: 20,000.

Vertical do. $1: 4,000,000$

Published by the Royal Geographical Societs. 


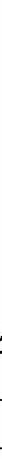

YRES AND ROSARIO RAILWAY.
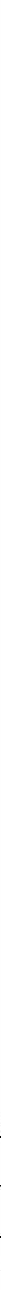
RNAL 1898.

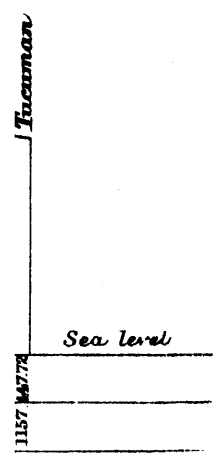

i

Sea level

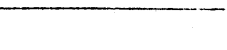

swerias, FR.G. 

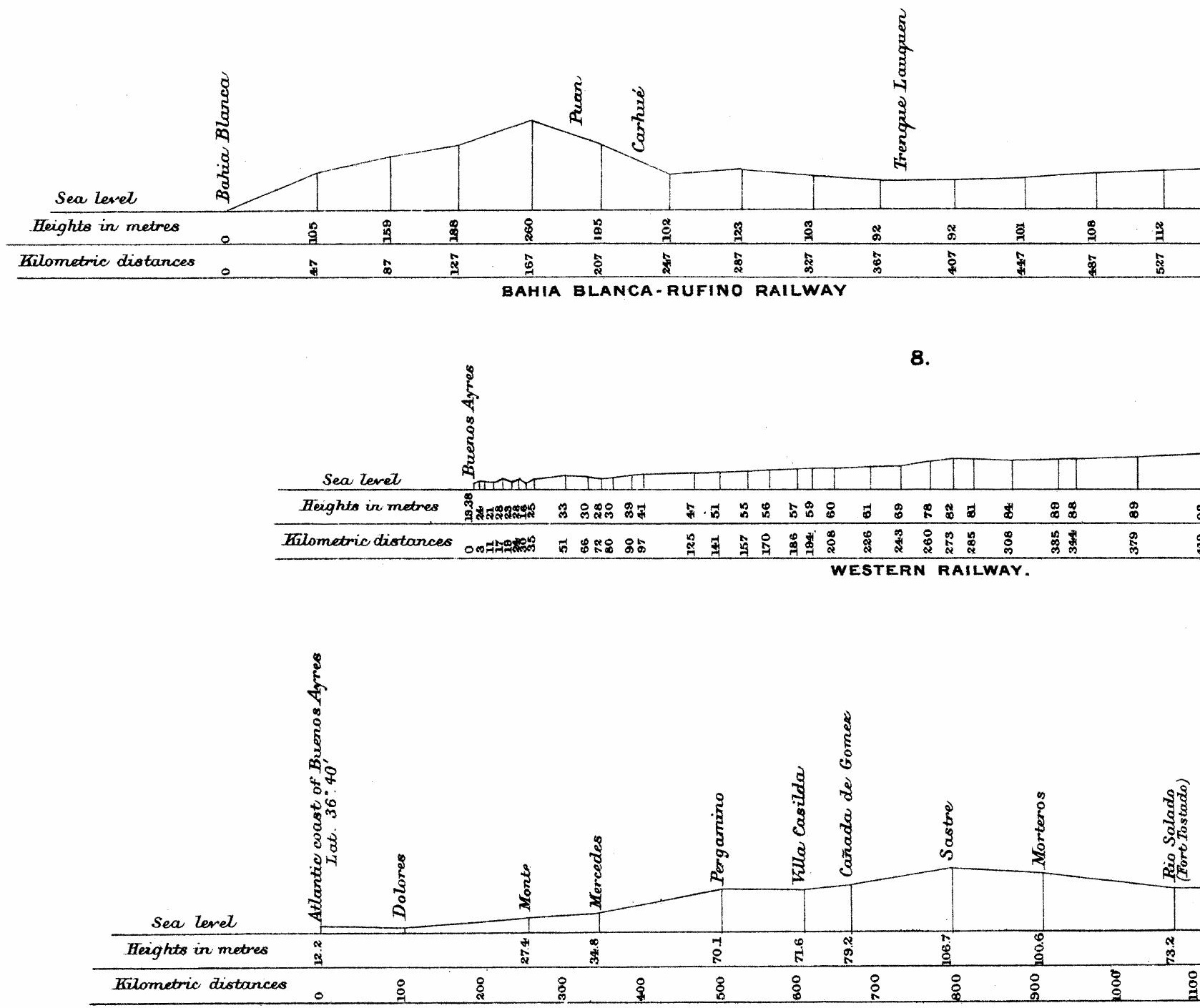

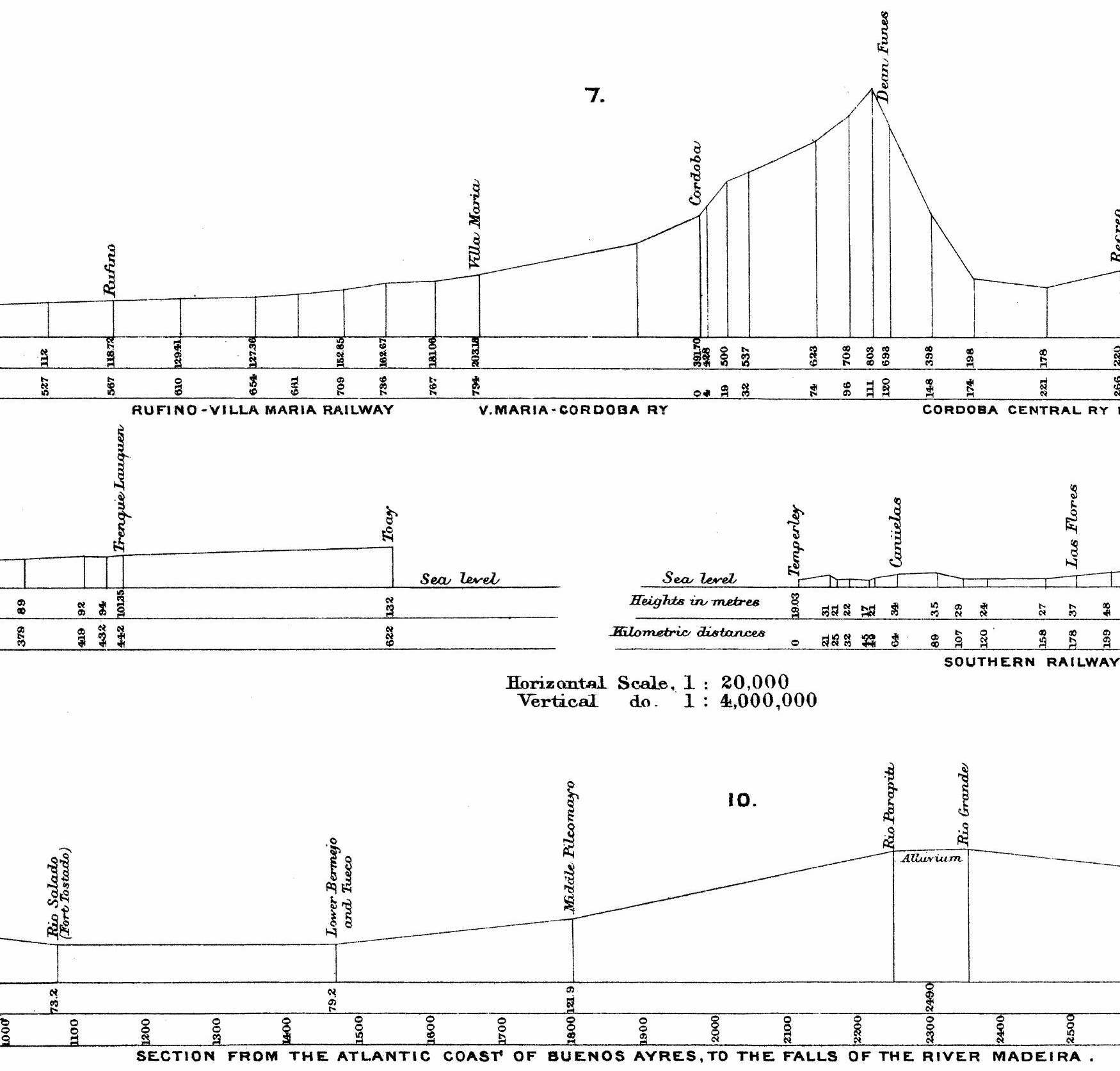

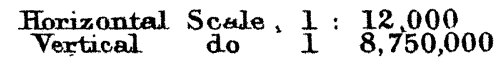

Published by the Royal Geogrophical Socicty. 


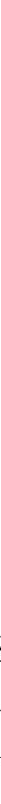

9.

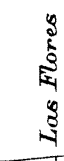

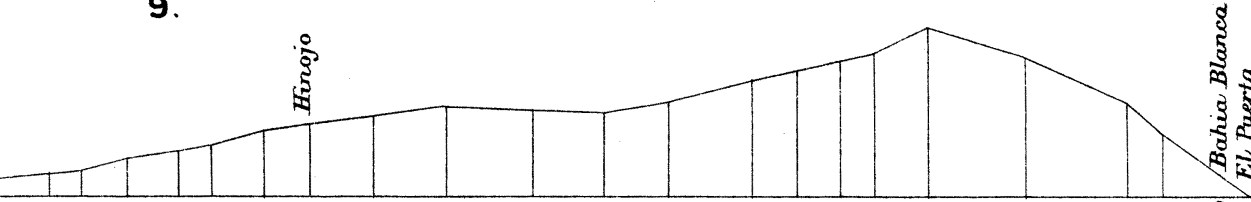

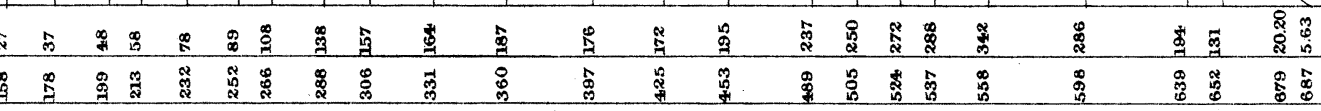

RAILWAY FROM TEMPERLEY (near the City of Buenos Ayres) TO BAHIA BLANCA.

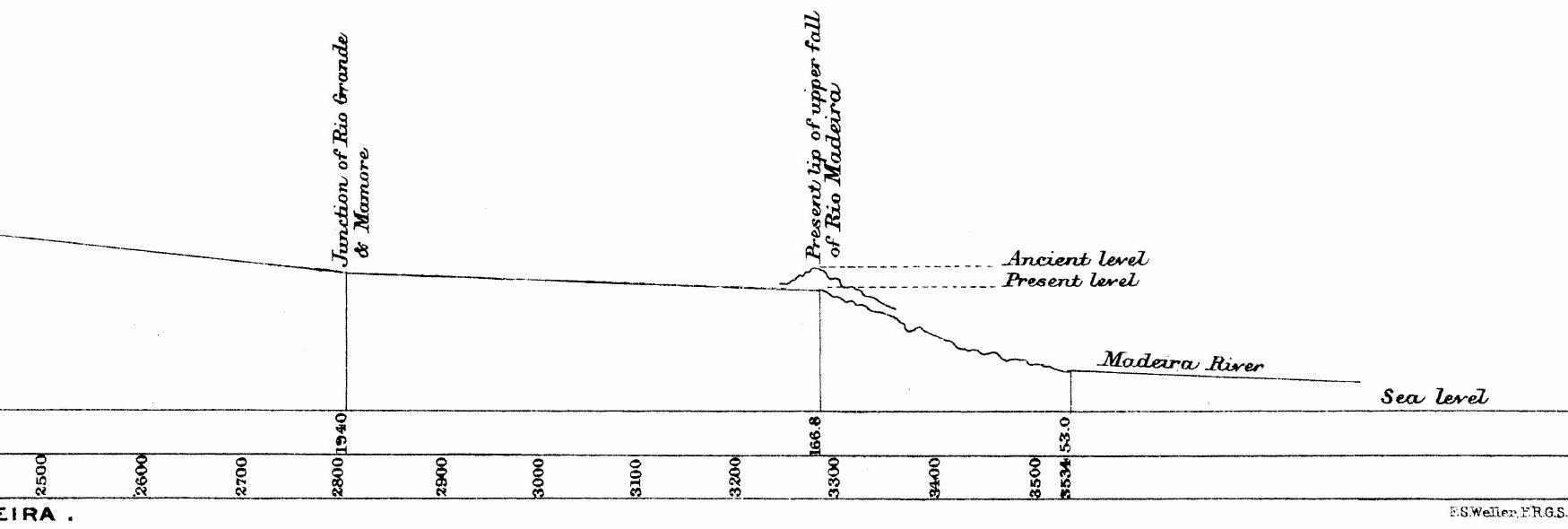


L JOURNAL .1898.

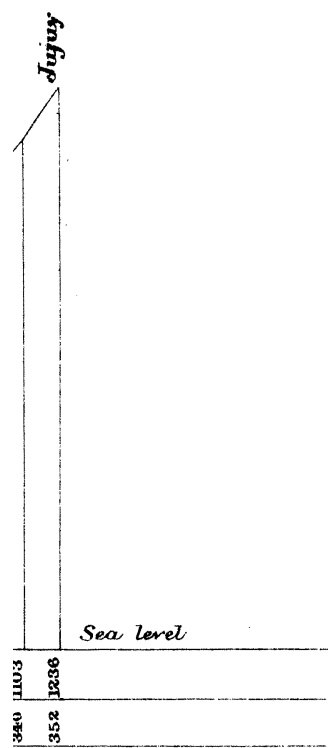

ret

S.WeT̃er.YR.G.S.

This content downloaded from 128.163.2.206 on Mon, 27 Jun 2016 05:01:06 UTC All use subject to http://about.jstor.org/terms 